\title{
Distribution and density of $\alpha$-and $\beta$-adrenergic receptor binding sites in the bovine mammary gland
}

\author{
BY HARALD M. HAMMON, RUPERT M. BRUCKMAIER, \\ ULRICH E. HONEGGER* AND JÜRG W. BLUM $\dagger$ \\ Institut für Tierzucht der Universität Bern, CH-3012 Bern, Schweiz \\ * Pharmakologisches Institut der Universität Bern, CH-3010 Bern, Schweiz
}

(Received 7 January 1993 and accepted for publication 7 May 1993)

Summary. Radioreceptor binding studies were designed to localize and determine the number of $\alpha$ - and $\beta$-adrenergic receptors in the mammary gland of lactating cows. ${ }^{3} \mathrm{H}$-prazosin, ${ }^{3} \mathrm{H}$-rauwolscine and ${ }^{3} \mathrm{H}$-dihydroalprenolol were used for the regional characterization of $\alpha_{1^{-}}, \alpha_{2^{-}}$and $\beta$-adrenergic receptors by competitive inhibition of binding of ${ }^{3} \mathrm{H}$-ligands with unlabelled adrenergic agonists and antagonists. The $\alpha_{1}-, \alpha_{2}$ and $\beta_{2}$-adrenergic receptor subtypes could thus be demonstrated in the regions of the teats, large mammary ducts and parenchyma. Tissues of the teat wall, of the large mammary ducts above the gland cistern and of the mammary parenchyma were prepared to determine the density of $\alpha_{1}, \alpha_{2}$ - and $\beta$ receptors by saturation binding assays using ${ }^{3} \mathrm{H}$-prazosin, ${ }^{3} \mathrm{H}$-rauwolscine and ${ }^{3} \mathrm{H}$ dihydroalprenolol respectively. Binding to high affinity sites was reversible within minutes and saturable. Equilibrium was reached within minutes. The number of $\alpha_{1}-$ and $\alpha_{2}$-adrenergic receptors decreased from the teat to the mammary ducts to the parenchyma. Most of the $\alpha_{1}$ - and $\alpha_{2}$-adrenergic receptors were found in the teat wall, whereas in the parenchyma $\alpha$-adrenergic receptors were absent or barely detectable. The density of $\beta$-adrenergic receptors was similar in the teat wall and the large mammary ducts, but much lower in the parenchyma. Thus, $\alpha_{1^{-}}, \alpha_{2}-$ and $\beta$-adrenergic receptors were found mainly in the milk purging system and hardly at all in mammary parenchyma. Inhibition of milk removal by $\alpha$-adrenergic stimulation is possibly due to constriction of teat wall and to constriction of the mammary ducts, whereas enhanced milk flow after $\beta$-adrenergic stimulation is possibly due to relaxation not only of the teat sphincter and teat wall, but probably also of the large mammary ducts.

The sympathetic nervous system is involved in peripheral modulation of milk removal. Milk yield was decreased during adrenalin, noradrenaline or $\alpha$-specific adrenergic agonist $(\alpha-\mathrm{Ag})$ administration. The inhibition of milk removal by the $\alpha$-Ag phenylephrine was shown to be dose-dependent (H. M. Hammon, unpublished observations). The effects were not mediated by inhibition of endogenous oxytocin release during milking (Lefcourt \& Akers, 1984; Blum et al. 1989). Furthermore, the inhibition of milk let-down by adrenergic drugs could be abolished by $\alpha$-, but not by $\beta$-adrenergic blockade (Blum et al. 1989). Contraction of both teat and gland cistern was observed using ultrasonography after $\alpha$-Ag administration (Bruckmaier \& Blum, 1992). Inhibition of milk removal by premilking electroshocks was abolished by

$\dagger$ For correspondence. 
$\alpha$-adrenergic blockade (Lefcourt \& Akers, 1982; Blum et al. 1989). These studies support the notion that catecholamines mediate their inhibitory effects on milk removal through stimulation of $\alpha$-adrenergic receptors located in the bovine mammary gland (Blum et al. 1989; Bruckmaier et al. 1991), most likely on smooth muscle cells not only in teats, but also in mammary ducts (Ziegler \& Mosimann, $1960)$. On the other hand, enhanced milk flow after administration of $\beta$-adrenergic agonists $(\beta-\mathrm{Ag})$ was ascribed to relaxation of the teat muscles and muscles around milk ducts leading from the alveolar tissue to the gland cistern (Hamann, 1981; Bruckmaier et al. 1991). Binding studies using radiolabelled adrenergic compounds as ligands indicated the existence of both $\alpha_{1}-$ and $\alpha_{2}$-adrenergic receptor subtypes and of the $\beta_{2}$-adrenergic receptor subtype, most likely on smooth muscles in the wall of the bovine teat, thus confirming radioligand binding studies on smooth muscles of the teat (Roets et al. 1984; Roets \& Peeters, 1985, 1986). Adrenergic receptor density in the teat muscles was related to milkability of lactating cows (Roets et al. 1989).

Because previous in vivo investigations suggested $\alpha$ - and $\beta$-adrenergic effects not only in the teat, but also in other regions of the udder (Bruckmaier et al. 1991; Bruckmaier \& Blum, 1992), the goal of the present investigations was the determination of $\alpha$ - and $\beta$-adrenergic receptors not only in the teat, but also in the region of the large mammary ducts and in the mammary parenchyma. The possible importance of the different regions of the mammary gland for inhibition of milk removal mediated by $\alpha$-adrenergic receptors and enhancement of milk flow mediated by $\beta$-adrenergic receptor interaction could thus be evaluated.

\section{MATERIALS AND METHODS}

\section{Preparation of membranes}

Tissues from three regions of lactating udders were used: the muscular layer of the teat (teat region), tissue around the gland cistern including the large mammary ducts (duct region), and mammary parenchyma from the dorsal udder in which mammary ducts were not visible macroseopically (parenchyma region). The material was removed immediately after slaughter and transferred on ice. The tissues of duct and parenchyma regions were minced into small pieces with scissors and put into ice cold 50 mm-Tris-HCl buffer, $\mathrm{pH} 7 \cdot 4$. The Tris-HCl buffer used in our assays contained $6 \mathrm{mM}-\mathrm{MgCl}_{2}$, essential for binding of the radiolabelled ligand (Moor et al. 1988), and $1 \mathrm{mm-EGTA}$ to chelate metals without affecting ligand binding (Parini et al. 1987). Teats were prepared as described by Roets et al. (1984). Internal mucosa and epidermis were removed, and the sphincter area of the teat was cut off and discarded. The tissue was suspended in $\sim 10-15$ volumes of buffer. All subsequent manipulations were carried out at $4{ }^{\circ} \mathrm{C}$. The material was homogenized four times for $20 \mathrm{~s}$ at low speed $(8000 \mathrm{rev} . / \mathrm{min})$ with an Ultra-Turrax homogenizer (T 25, Janke \& Kunkel, Staufen, Germany). The homogenate was centrifuged at $500 \mathrm{~g}$ for $10 \mathrm{~min}$; the supernatant was passed through two layers of cheesecloth and then centrifuged at $49000 \mathrm{~g}$ and $4{ }^{\circ} \mathrm{C}$ for $30 \mathrm{~min}$ (Moor et al. 1988). The resulting supernatant was decanted completely and the remaining pellet was suspended in ice cold buffer (as above) by a motor-driven Glass-Teflon homogenizer.

The protein concentration was determined using a kit (BCA Protein Assay Reagent; Pierce, Rockford, IL, USA) and the membrane suspension was then adjusted to $200-300 \mu \mathrm{g}$ protein $/ 100 \mu \mathrm{l}$. Specific ${ }^{3} \mathrm{H}$-ligand binding was plotted against protein concentration and was shown to increase with increasing membrane protein concentration, as expected (results not shown). Protein concentration was 
kept constant (200 or $300 \mu \mathrm{g} / 100 \mu \mathrm{l}$ ) throughout. While membrane suspensions used for competitive binding assays were frozen in liquid nitrogen and stored at $-80^{\circ} \mathrm{C}$, saturation binding assays were carried out immediately after preparation of the membrane suspension. Freezing of membranes did not affect binding as such, but preliminary studies demonstrated some reduction in the number of binding sites (Shi et al. 1989).

\section{Binding studies}

$\alpha_{1}$-Adrenergic receptor binding was tested by use of ${ }^{3} \mathrm{H}$-prazosin, a highly $\alpha_{1}$ selective antagonist (Shi et al. 1989), $\alpha_{2}$-adrenergic receptor binding with ${ }^{3} \mathrm{H}$ rauwolscine, an $\alpha_{2}$-selective antagonist (Shi et al. 1989), and $\beta$-adrenergic binding with ${ }^{3} \mathrm{H}$-dihydroalprenolol $\left({ }^{3} \mathrm{H}\right.$-DHA), a non-selective $\beta$-adrenergic antagonist (Hancock et al. 1979). Saturation binding assays were performed to determine binding capacity. Competitive binding assays with different specific unlabelled ligands were performed to characterize the receptor subtype.

Saturation binding assays. These assays were carried out to investigate the distribution of ${ }^{3} \mathrm{H}$-prazosin $(n=7),{ }^{3} \mathrm{H}$-rauwolscine $(n=4)$ and ${ }^{3} \mathrm{H}-\mathrm{DHA}(n=7)$ binding sites in teat, duct and parenchyma regions, where $n$ is the number of udders. Membrane suspensions $(100 \mu \mathrm{l})$ were incubated with increasing concentrations of the ${ }^{3} \mathrm{H}$-labelled ligand with or without unlabelled ligand $(50 \mu \mathrm{l})$ at $37^{\circ} \mathrm{C}$ for $15 \mathrm{~min}$ with constant shaking to determine total and non-specific binding. All drugs were diluted in the Tris- $\mathrm{HCl}$ buffer described above. The binding reaction was terminated by adding $1 \mathrm{ml}$ of ice cold buffer and the material was immediately passed through glass fibre filters (diam. $20 \mathrm{~mm}$; Whatman GF/C, Whatman International, Maidstone ME14 2LE, UK or MN GF-3; Macherey-Nagel, Düren, Germany), using a vacuum filtration manifold (Hölzel, Dorfen, Germany). Filters were rapidly washed three times with $5 \mathrm{ml}$ saline $(9 \mathrm{~g} / \mathrm{l})$, dried and placed into plastic vials. Scintillation cocktail (3 ml ; OptiPhase 'HiSafe' II ; FSA Laboratory, Loughborough LE11, UK) was added and the bound ${ }^{3} \mathrm{H}$-activity was measured in a liquid scintillation counter (BETAmatic, Kontron, Switzerland).

Specific binding of the ${ }^{3} \mathrm{H}$-ligand was calculated. For testing $\alpha_{1}$ - and $\alpha_{2}$-adrenergic receptor binding, $10 \mu \mathrm{m}$ phentolamine (final concentration) was used as the unlabelled ligand (or competitor), whereas for evaluation of the $\beta$-adrenergic receptor binding $1 \mu \mathrm{M}-( \pm)$-propranolol (final concentration) was used as competitor. Specific binding represented $60-95 \%$ of the total binding depending on mammary tissue site and on the type of the ${ }^{3} \mathrm{H}$-labelled ligand.

Specific binding was expressed as fmol bound ${ }^{3} \mathrm{H}$-ligand per $\mathrm{mg}$ of membrane protein. Equilibrium binding data were plotted as a function of ${ }^{3} \mathrm{H}$-ligand concentration (saturation curve). Maximal binding capacities $\left(B_{\max }\right)$ and equilibrium dissociation constants $\left(K_{\mathrm{D}}\right)$ were calculated by a curve-fitting computer program (Motulsky, 1987).

Competitive binding assays. These experiments were performed by incubating membrane preparations $(100 \mu \mathrm{l})$ with a fixed concentration of ${ }^{3} \mathrm{H}$-labelled ligand $(50 \mu \mathrm{l})$ and a series of competitors (non-radioactive $\alpha$-or $\beta$-Ag or blocking agents) at eight or ten concentrations. Final concentrations of ${ }^{3} \mathrm{H}$-prazosin, ${ }^{3} \mathrm{H}$-rauwolscine and ${ }^{3} \mathrm{H}$-DHA were 1,5 and $2 \mathrm{~nm}$ respectively. The procedures used to determine radiolabelled binding were similar to those described for saturation binding assay but used membrane suspensions obtained from the duct region of several udders.

Binding kinetics. ${ }^{3} \mathrm{H}$-ligand binding kinetics were studied using a single concentration of the ${ }^{3} \mathrm{H}$-ligand under standard assay conditions at different 
incubation times. Final concentrations of ${ }^{3} \mathrm{H}$-prazosin, ${ }^{3} \mathrm{H}$-rauwolscine and ${ }^{3} \mathrm{H}-\mathrm{DHA}$ were 1,5 and $2 \mathrm{~nm}$ respectively. Assays with ${ }^{3} \mathrm{H}$-prazosin and ${ }^{3} \mathrm{H}-\mathrm{DHA}$ were performed at $37^{\circ} \mathrm{C}$. Assays with ${ }^{3} \mathrm{H}$-rauwolscine were carried out at $25^{\circ} \mathrm{C}$ to maintain the reversibility of specific binding. In assays with ${ }^{3} \mathrm{H}$-prazosin and ${ }^{3} \mathrm{H}$ DHA the competitor was added after 10 min of binding reaction, in assays with ${ }^{3} \mathrm{H}$ rauwolscine after 6 min.

\section{Drugs}

${ }^{3} \mathrm{H}$-prazosin $(81 \mathrm{Ci} / \mathrm{mmol}),{ }^{3} \mathrm{H}$-rauwolscine $(84 \mathrm{Ci} / \mathrm{mmol})$ and ${ }^{3} \mathrm{H}-\mathrm{DHA}(83 \mathrm{Ci} /$ mmol) were purchased from Amersham International ple (Aylesbury HP20 2TP, $\mathrm{UK}) ;(-)$-noradrenaline-L-hydrogen tartrate, dopamine-HCl and $( \pm)$-isoproterenol from Fluka AG (Buchs, Switzerland); ( \pm )-propranolol from Imperial Chemical Industries (Macclesfield, UK); (-)-adrenalin(+)-bitartrate, (-)-propranolol, (+)propranolol, prazosin-HCl, (-)-alprenolol hydrate, atenolol, (-)-phenylephrine$\mathrm{HCl}$, fenoterol- $\mathrm{HBr}$, yohimbine- $\mathrm{HCl}$ and clonidine- $\mathrm{HCl}$ from Sigma (St Louis, MO 63178, USA). Phentolamine mesylate and rauwolscine- $\mathrm{HCl}$ were purchased from Research Biochemicals Inc. (Natick, MA, USA). Dihydroergocryptine and dihydroergotamine were kindly donated by Sandoz AG (Basle) and clenbuterol by Bayer AG (Wuppertal, Germany).

Solutions were prepared freshly before each assay and substances were dissolved in Tris-HCl buffer (see above). If necessary, especially when using lipophilic agents (rauwolscine, yohimbine or prazosin), ethanol $(980 \mathrm{ml} / \mathrm{l})$ was added to promote dissolution. In this quantity ( $50 \mathrm{~mm}$ final concentration in the incubation media), ethanol does not modify binding (Roets et al. 1984).

\section{Mathematical and statistical evaluation}

For data analysis we used the GraphPAD computer program (Motulsky, 1987). Weighted least squares curve fitting of binding values was performed to analyse saturation and competitor displacement studies. For statistical evaluation of the results, the SAS program package (SAS, 1990, release 6.04) was employed. Competitor displacement and receptor density were tested for significance of difference $(P<0.05)$ by means of Wilcoxon's two-sample test. All values are presented as means \pm SEM.

\section{Binding kinetics}

\section{RESULTS}

${ }^{3} \mathrm{H}$-prazosin, ${ }^{3} \mathrm{H}$-rauwolscine and ${ }^{3} \mathrm{H}$-DHA binding was rapid and steady state conditions were reached within minutes (Fig. 1). There was dissociation of binding within minutes after addition of competitors at $37^{\circ} \mathrm{C}$ for ${ }^{3} \mathrm{H}$-prazosin and ${ }^{3} \mathrm{H}-\mathrm{DHA}$, but only at $25^{\circ} \mathrm{C}$ for ${ }^{3} \mathrm{H}$-rauwolscine.

\section{Competitive binding assays}

The $K_{i}$-values and Hill coefficients $(h)$ for inhibition of specific ${ }^{3} \mathrm{H}$-prazosin binding by adrenergic competitors are shown in Table 1. For ${ }^{3} \mathrm{H}$-prazosin binding the $K_{i}$ value of the unlabelled $\alpha_{1}$-antagonist prazosin was lowest while the $\alpha_{2}$-selective antagonist yohimbine and the $\alpha_{2}$-selective agonist clonidine had $\sim 1000$-fold higher $K_{i}$ values than unlabelled prazosin $(P<0.05)$. The non-selective $\alpha$-adrenergic antagonist phentolamine and the $\alpha$-adrenergic agents dihydroergotamine and dihydroergocryptine were $\sim 30-50$ times less potent than unlabelled prazosin for inhibiting binding $(P<0.05)$. The $K_{i}$ value of phenylephrine, an $\alpha_{1}$-agonist, was very high compared with the other $\alpha$-adrenergic competitors. Isoproterenol, a $\beta$ - 

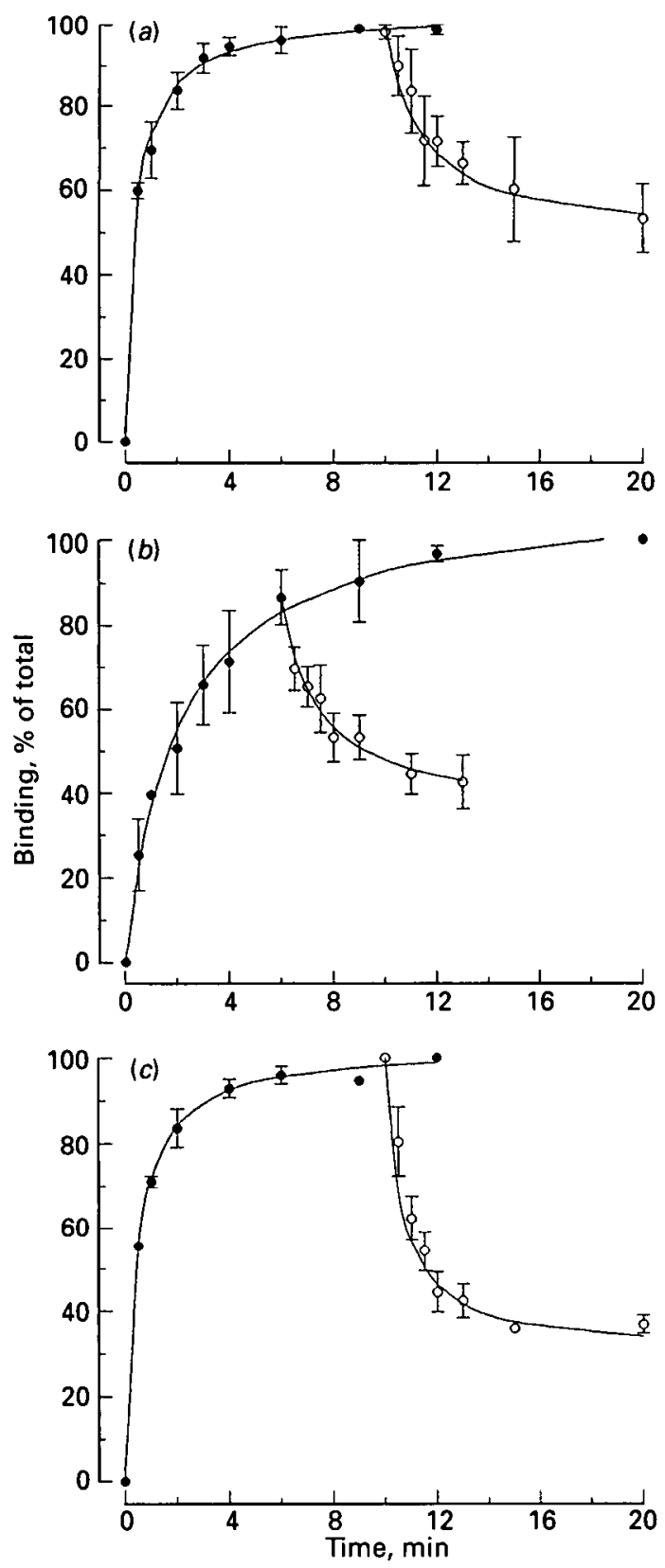

Fig. 1. Binding of $(a){ }^{3} \mathrm{H}$-prazosin, $(b){ }^{3} \mathrm{H}$-rauwolscine and $(c){ }^{3} \mathrm{H}$-dihydroalprenolol to membranes of mammary duct tissue from the udders of three cows: $O$, association; $O$, dissociation. The competitor was (a) $10 \mu \mathrm{M}$-phentolamine added at $10 \mathrm{~min},(b) 10 \mu \mathrm{m}$-phentolamine added at $6 \mathrm{~min}$, (c) $1 \mu \mathrm{M}$ propanolol added at $10 \mathrm{~min}$; total binding of the radiolabelled ligand was taken as $100 \%$.

adrenergic agonist, displaced ${ }^{3} \mathrm{H}$-prazosin binding only at very high concentrations. The order of potency for inhibition of ${ }^{3} \mathrm{H}$-prazosin binding was prazosin $>$ phentolamine $>$ dihydroergotamine $>$ dihydroergocryptine $>$ yohimbine $>$ clonidine $>$ adrenalin $>$ noradrenaline $>$ phenylephrine $>$ isoproterenol $>$ dopamine. Most of the Hill coefficients were close to one, except for phentolamine, a non-selective $\alpha$-antagonist. 
Table 1. Inhibition of specific ${ }^{3} \mathrm{H}$-prazosin binding by adrenergic agonists and antagonists (competitors) on membranes of the duct region of the udder

(Values for $K_{i}$ and $h$ are mean \pm sem for $n$ udders)

Competitor
Prazosin
Phentolamine
Dihydroergotamine
Dihydroergocryptine
Yohimbine
Clonidine
Adrenalin
Noradrenaline
Phenylephrine
Isoproterenol
Dopamine

Competitor dissociation

constant $\left(K_{i}\right)$, м

$1 \cdot 0 \pm 0.2 \times 10^{-9 \mathrm{a}}$

$2 \cdot 7 \pm 0 \cdot 3 \times 10^{-8} b$

$5 \cdot 0 \pm 2.0 \times 10^{-8} \mathrm{~b}$

$6 \cdot 2 \pm 1.7 \times 10^{-8} \mathrm{~b}$

$1 \cdot 1 \pm 0.2 \times 10^{-6 \mathrm{c}}$

$1 \cdot 3 \pm 0.1 \times 10^{-6 \mathrm{c}}$

$3 \cdot 7 \pm 0 \cdot 5 \times 10^{-6} \mathrm{~d}$

$6 \cdot 7 \pm 0.7 \times 10^{-6} \mathrm{e}$

$2.2 \pm 0.3 \times 10^{-5} \mathrm{~s}$

$8 \cdot 8 \pm 1 \cdot 3 \times 10^{-5 g}$

$5 \cdot 1 \pm 0 \cdot 4 \times 10^{-4 h}$

Potency ratio
1.0000
0.0370
0.0200
0.0161
0.0009
0.0008
0.0003
0.0001
0.0000
0.0000
0.0000

\begin{tabular}{|c|}
\hline $\begin{array}{l}\text { Hill coefficient } \\
\text { of plot }(h)\end{array}$ \\
\hline $0 \cdot 90 \pm 0 \cdot 10$ \\
\hline $0.64 \pm 0.03$ \\
\hline $0.83 \pm 0.07$ \\
\hline $0.87 \pm 0.06$ \\
\hline $0.80 \pm 0.04$ \\
\hline $0.84 \pm 0.11$ \\
\hline $0.80 \pm 0.09$ \\
\hline $0.79 \pm 0.03$ \\
\hline $0.79 \pm 0.04$ \\
\hline $0.91 \pm 0.08$ \\
\hline $0.87 \pm 0.06$ \\
\hline
\end{tabular}

a, b, c, d, e, $, \mathbf{B}, \mathbf{h}$ Means without common superscript letters were significantly different $(P<0 \cdot 05)$.

Table 2. Inhibition of specific ${ }^{3} H$-rauwolscine binding by adrenergic agonists and antagonists (competitors) on membranes of the duct region of the udder

(Values for $K_{i}$ and $h$ are mean $\pm \operatorname{seM}$ for $n$ udders)

\begin{tabular}{|c|c|c|c|}
\hline Competitor & $\begin{array}{l}\text { Competitor dissociation } \\
\text { constant }\left(K_{i}\right), \mathbf{M}\end{array}$ & Potency ratio & $\begin{array}{l}\text { Hill coefficient } \\
\text { of plot }(h)\end{array}$ \\
\hline Rauwolscine & $3 \cdot 1 \pm 0 \cdot 4 \times 10^{-8 \text { a }}$ & $1 \cdot 0000$ & $1 \cdot 10 \pm 0 \cdot 19$ \\
\hline Clonidine & $5 \cdot 2 \pm 0.9 \times 10^{-8 a b}$ & 0.5960 & $0.68 \pm 0.06$ \\
\hline Phentolamine & $5.4 \pm 3.0 \times 10^{-8 \mathrm{ab}}$ & 0.5740 & $0.73 \pm 0.08$ \\
\hline Yohimbine & $8.4 \pm 1.6 \times 10^{-8}$ & $0 \cdot 3690$ & $0 \cdot 70 \pm 0 \cdot 07$ \\
\hline Prazosin & $3.3 \pm 0.6 \times 10^{-6 c}$ & $0 \cdot 0090$ & $1.00 \pm 0.24$ \\
\hline Adrenalin & $3.5 \pm 0.7 \times 10^{-6 c}$ & 0.0089 & $0.70 \pm 0.05$ \\
\hline Noradrenaline & $1 \cdot 0 \pm 0.2 \times 10^{-5 d}$ & 0.0030 & $0 \cdot 85 \pm 0.05$ \\
\hline Phenylephrine & $4 \cdot 1 \pm 1 \cdot 6 \times 10^{-5 d}$ & 0.0008 & $0.98 \pm 0.11$ \\
\hline Dopamine & $1 \cdot 3 \pm 0.2 \times 10^{-4} \mathrm{e}$ & 0.0002 & $0.87 \pm 0.03$ \\
\hline Isoproterenol & $25 \pm 0.2 \times 10^{-4 P}$ & 0.0001 & $0.99 \pm 0.15$ \\
\hline
\end{tabular}

a.b.c,d,e.f Means without common superscript letters were significantly different $(P<0 \cdot 05)$.

Table 3. Inhibition of specific ${ }^{3} H$-dihydroalprenolol binding by adrenergic agonists and antagonists (competitors) on membranes of the duct region of the udder

(Values for $K_{i}$ and $h$ are mean $\pm \operatorname{sem}$ for $n$ udders)

Competitor
(-)-Propranolol
Alprenolol
(士)-Propranolol
Clenbuterol
(+)-Propranolol
Fenoterol
Isoproterenol
Adrenalin
Noradrenaline
Atenolol
Dopamine

\begin{tabular}{|c|c|c|}
\hline $\begin{array}{l}\text { Competitor dissociation } \\
\text { constant }\left(K_{i}\right), \mathrm{M}\end{array}$ & Potency ratio & $\begin{array}{l}\text { Hill coefficient } \\
\text { of plot }(h)\end{array}$ \\
\hline $3 \cdot 5 \pm 0.5 \times 10^{-9 a}$ & 1.0000 & $0.72 \pm 0.08$ \\
\hline $3 \cdot 7 \pm 0.7 \times 10^{-9 a}$ & 1.0000 & $0.91 \pm 0.13$ \\
\hline $8 \cdot 6 \pm 0.8 \times 10^{-9 b}$ & $0 \cdot 4444$ & $0.98 \pm 0.08$ \\
\hline $4.9 \pm 0.7 \times 10^{-8 \mathrm{c}}$ & $0 \cdot 0816$ & $0.99 \pm 0.06$ \\
\hline $3.2 \pm 0.5 \times 10^{-7}$ & 0.0124 & $1 \cdot 22 \pm 0 \cdot 13$ \\
\hline $4 \cdot 8 \pm 1 \cdot 1 \times 10^{-7} \mathrm{~d}$ & 0.0084 & $0.94 \pm 0.05$ \\
\hline $9 \cdot 1 \pm 2.6 \times 10^{-7 d}$ & 0.0044 & $0 \cdot 88 \pm 0.03$ \\
\hline $2 \cdot 2 \pm 0.3 \times 10^{-6} \mathrm{e}$ & 0.0018 & $0 \cdot 86 \pm 0 \cdot 14$ \\
\hline $1 \cdot 7 \pm 0.3 \times 10^{-5}$ & $0 \cdot 0002$ & $1 \cdot 24 \pm 0.28$ \\
\hline $39 \pm 1.3 \times 10^{-5 !}$ & 0.0001 & $0 \cdot 73 \pm 0.08$ \\
\hline $38 \pm 1.9 \times 10^{-48}$ & 0.0000 & $0 \cdot 95 \pm 0 \cdot 10$ \\
\hline
\end{tabular}

a.b.c.d,e.p.g Means without common superscript letters were significantly different $(P<0 \cdot 05)$. 

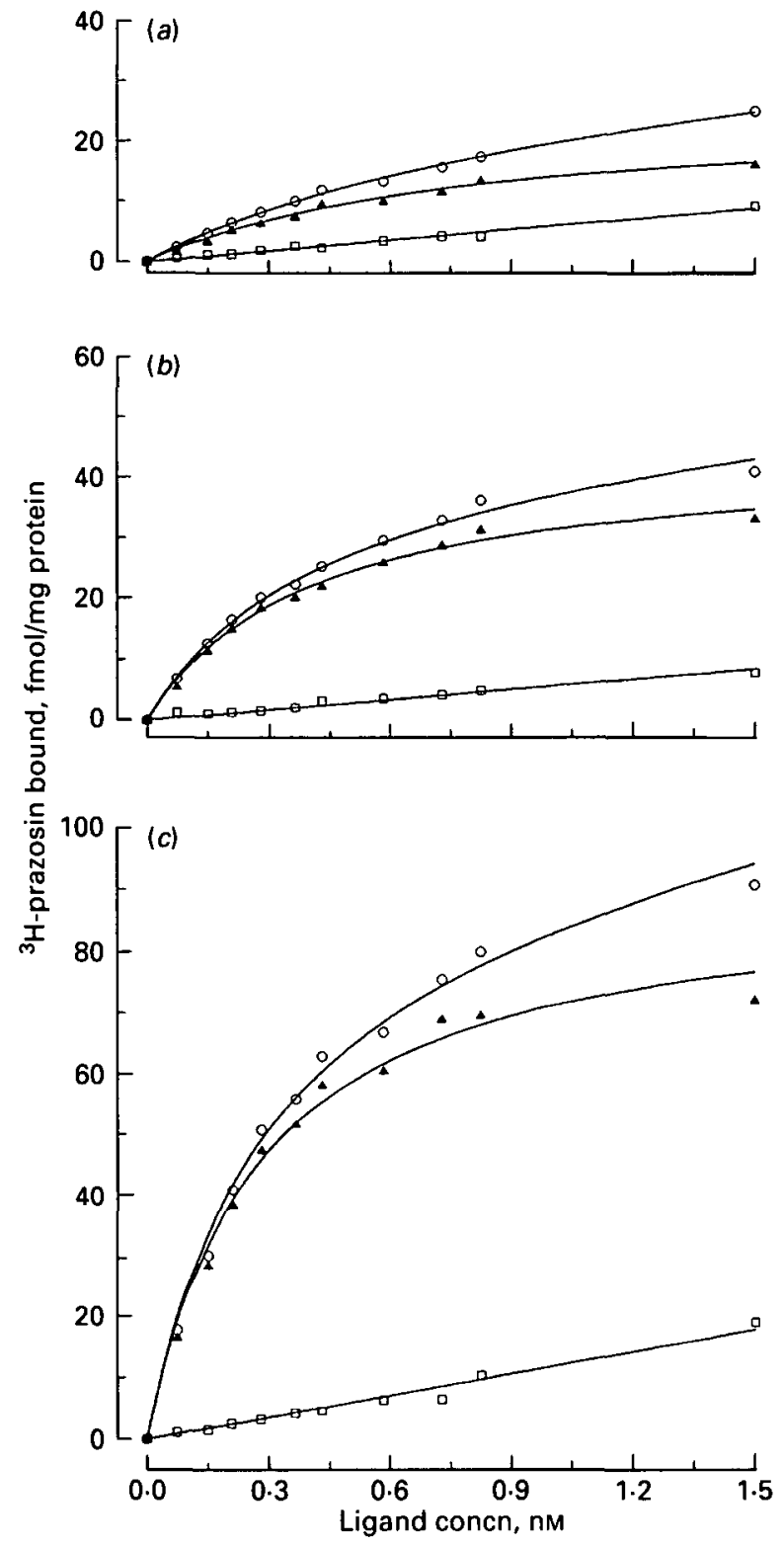

Fig. 2. Representative saturation plot for binding of the $\alpha$-antagonist ${ }^{3} \mathrm{H}$-prazosin to suspensions of membrane preparations of $(a)$ parenchyma, $(b)$ mammary duct and $(c)$ teat regions of one bovine udder: $O$, total binding; $\square$, non-specific binding; $\boldsymbol{\Delta}$, specific binding. Each point is the mean of triplicate determinations.

The $\alpha_{2}$-adrenergic competitors rauwolscine, clonidine, and yohimbine had low, and similar, $K_{i}$ values for displacement of specific ${ }^{3} \mathrm{H}$-rauwolscine binding (Table 2). Inhibition potency of the non-selective $\alpha$-adrenergic antagonist phentolamine was of the same order of magnitude, whereas the $\alpha_{1}$-antagonist prazosin was about 100 times less potent than unlabelled rauwolscine for inhibition of ${ }^{3} \mathrm{H}$-rauwolscine binding $(P<0.05)$. Displacement by isoproterenol of ${ }^{3} \mathrm{H}$-rauwolscine binding was in agreement with displacement of ${ }^{3} \mathrm{H}$-prazosine from its binding sites. The order of potency for inhibition of ${ }^{3} \mathrm{H}$-rauwolscine binding was rauwolscine $>$ clonidine $>$ 
Table 4. Values from saturation assays of ${ }^{3} \mathrm{H}$-prazosin, ${ }^{3} \mathrm{H}$-rauwolscine and ${ }^{3} \mathrm{H}$ dihydroalprenolol binding on membranes of different regions of the udder

(Values are means \pm SEM for no. of udders shown)

\begin{tabular}{|c|c|c|c|c|}
\hline Ligand & Region & $\begin{array}{l}\text { Maximal binding } \\
\text { capacity }\left(B_{\max }\right) \\
\text { fmol/mg protein }\end{array}$ & $\begin{array}{c}\text { Dissociation } \\
\text { constant }\left(K_{\mathrm{D}}\right), \mathrm{nM}\end{array}$ & $\begin{array}{c}\text { Hill coefficient } \\
(h)\end{array}$ \\
\hline $\begin{array}{l}{ }^{3} \mathrm{H} \text {-prazosin } \\
\text { (7 udders) }\end{array}$ & $\begin{array}{l}\text { Teat } \\
\text { Mammary duct } \\
\text { Parenchyma }\end{array}$ & $\begin{array}{c}126 \cdot 4 \pm 25 \cdot 4^{\mathrm{a}} \\
38 \cdot 8 \pm 6 \cdot 3^{\mathrm{b}} \\
7 \cdot 8 \pm 3 \cdot 4^{\mathrm{c}}\end{array}$ & $\begin{array}{l}0 \cdot 38 \pm 0 \cdot 03 \\
0 \cdot 34 \pm 0 \cdot 05 \\
0 \cdot 58 \pm 0 \cdot 13\end{array}$ & $\begin{array}{l}0.92 \pm 0.06 \\
0.97 \pm 0.03 \\
1.01 \pm 0.01\end{array}$ \\
\hline $\begin{array}{c}{ }^{3} \text { H-rauwolscine } \\
\text { (4 udders) }\end{array}$ & $\begin{array}{l}\text { Teat } \\
\text { Mammary duct } \\
\text { Parenchyma }\end{array}$ & $\begin{array}{c}130 \cdot 1 \pm 21 \cdot 6^{\mathrm{a}} \\
23 \cdot 4 \pm 9 \cdot 4^{\mathrm{b}} \\
<3 \cdot 0\end{array}$ & $\begin{array}{l}4 \cdot 42 \pm 0 \cdot 68 \\
4 \cdot 38 \pm 1 \cdot 37\end{array}$ & $\begin{array}{l}1 \cdot 05 \pm 0.08 \\
1.09 \pm 0.04\end{array}$ \\
\hline $\begin{array}{l}{ }^{3} \mathrm{H}-\mathrm{DHA} \\
\text { (7 udders) }\end{array}$ & $\begin{array}{l}\text { Teat } \\
\text { Mammary duct } \\
\text { Parenchyma }\end{array}$ & $\begin{array}{c}123 \cdot 3 \pm 21 \cdot 2^{\mathrm{a}} \\
119 \cdot 1 \pm 21 \cdot 8^{\mathrm{a}} \\
23 \cdot 7 \pm 5 \cdot 3^{\mathrm{b}}\end{array}$ & $\begin{array}{l}1 \cdot 13 \pm 0 \cdot 23 \\
1 \cdot 41 \pm 0 \cdot 15 \\
1 \cdot 78 \pm 0 \cdot 43\end{array}$ & $\begin{array}{l}0 \cdot 96 \pm 0.001 \\
0.97 \pm 0.01 \\
1 \cdot 07 \pm 0.03\end{array}$ \\
\hline
\end{tabular}

a, b, c Means without common superscript letters were significantly different between regions within ligand $(P<0 \cdot 05)$.

phentolamine $>$ yohimbine $>$ prazosin $>$ adrenalin $>$ noradrenaline $>$ phenylephrine $>$ dopamine $>$ isoproterenol. Hill coefficients were in the same range as in ${ }^{3} \mathrm{H}$-prazosin binding studies.

The unlabelled non-selective $\beta$-antagonists alprenolol and propranolol had the lowest $K_{i}$ values for specific ${ }^{3} \mathrm{H}$-DHA binding sites, followed by the $\beta_{2}$-adrenergic agonist clenbuterol (Table 3 ). The $\beta_{2}$-agonist fenoterol and the non-selective $\beta$ agonist isoproterenol were about 100 -fold more potent than the $\beta_{1}$-antagonist atenolol for inhibition of ${ }^{3} \mathrm{H}-\mathrm{DHA}$ binding $(P<0.05)$. The order of potency for inhibition of ${ }^{3} \mathrm{H}$-DHA binding was alprenolol $>$ propranolol $>$ clenbuterol $>$ fenoterol $>$ isoproterenol $>$ adrenalin $>$ noradrenaline $>$ atenolol $>$ dopamine. Inhibition of ${ }^{3} \mathrm{H}$-DHA binding was investigated with different isomers of propranolol. The order of potency was dependent on stereospecificity: $(-)$-propranolol $>( \pm)$ propranolol $(P<0.05)>(+)$-propranolol $(P<0.05$; Table 3$)$. Most of the substances competed for ${ }^{3} \mathrm{H}$-DHA binding with Hill coefficients close to one, except for $(-)$ propranolol and atenolol.

\section{Saturation binding assays}

The specific binding of ${ }^{3} \mathrm{H}$-prazosin to membrane suspensions was a saturable process (Fig. 2). There was a decrease in the density of ${ }^{3} \mathrm{H}$-prazosin binding sites from the teat region to the duct region to the parenchyma region $(P<0.05$; Table 4$) . K_{\mathrm{D}}$ values of the three udder regions were in the same range. Hill coefficients were all close to one.

The specific binding of ${ }^{3} \mathrm{H}$-rauwolscine to membrane suspensions was a saturable process. There was a decrease in the number of ${ }^{3} \mathrm{H}$-rauwolscine binding sites from the teat to the duct region $(P<0.05$; Table 4$)$. In the parenchyma region no specific ${ }^{3} \mathrm{H}$ rauwolscine binding could be measured. $K_{\mathrm{D}}$ values of the teat and duct region were in the same range. Hill coefficients were all close to one.

The specific binding of ${ }^{3} \mathrm{H}$-DHA was saturable for each udder region. Numbers of binding sites for ${ }^{3} \mathrm{H}$-DHA were similar in the teat and duct regions, but markedly lower in the parenchyma region $(P<0.05$; Table 4$) . K_{\mathrm{D}}$ values of the three udder regions were of the same order. However, $K_{\mathrm{D}}$ values for ${ }^{3} \mathrm{H}$-prazosin, ${ }^{3} \mathrm{H}$-rauwolscine and ${ }^{3} \mathrm{H}$-DHA binding were significantly different $(P<0 \cdot 05)$. All Hill coefficients were close to one. 
DISCUSSION

Kinetic experiments demonstrated the reversibility of ${ }^{3} \mathrm{H}$-prazosin, ${ }^{3} \mathrm{H}$ rauwolscine and ${ }^{3} \mathrm{H}$-DHA binding. Association of ${ }^{3} \mathrm{H}$-rauwolscine had to be studied at $25^{\circ} \mathrm{C}$ and an excess of unlabelled phentolamine had to be added after only 6 min because ${ }^{3} \mathrm{H}$-rauwolscine binding was no longer reversible with incubation for longer times or at $37^{\circ} \mathrm{C}$. This was surprising, because competitive binding assays with simultaneous addition of rauwolscine and phentolamine at $37^{\circ} \mathrm{C}$ caused inhibition of ${ }^{3} \mathrm{H}$-rauwolscine binding.

Three different adrenergic receptor subtypes $\left(\alpha_{1}, \alpha_{2}, \beta_{2}\right)$ could be identified by inhibition of specific ${ }^{3} \mathrm{H}$-prazosin, ${ }^{3} \mathrm{H}$-rauwolscine and ${ }^{3} \mathrm{H}$-DHA binding by different subtype-specific drugs.

From the characteristics of Scatchard and Hill plots, ${ }^{3} \mathrm{H}$-prazosin, ${ }^{3} \mathrm{H}$-rauwolscine and ${ }^{3} \mathrm{H}$-DHA saturation binding indicated interaction with only a single binding site, identified as $\alpha_{1^{-}}, \alpha_{2^{-}}$and $\beta_{2^{-}}$-adrenergic receptor subtypes respectively. $K_{\mathrm{D}}$ values calculated for ${ }^{3} \mathrm{H}$-prazosin, ${ }^{3} \mathrm{H}$-rauwolscine and ${ }^{3} \mathrm{H}$-DHA binding were significantly different from each other. On the other hand, $K_{\mathrm{D}}$ values of the same ${ }^{3} \mathrm{H}$-ligand for teat, duct and parenchyma region were of the same order. Numbers of $\alpha_{1^{-}}, \alpha_{2^{-}}$and $\beta_{2}$-adrenergic receptors of membranes obtained from the teat region agreed well with the results of Roets et al. (1984) and Roets \& Peeters (1985, 1986). Our studies demonstrate that there are additional regions in the bovine mammary gland containing $\alpha_{1}-, \alpha_{2}$ - and $\beta_{2}$-adrenergic receptors, localized in the area around the gland cistern including the large mammary ducts. However, it is important to note that the parenchyma region contained only very small numbers of adrenergic receptors. Thus, adrenergic receptors were mainly present in the milk purging system of the udder.

That $\alpha$-adrenergic receptors were specifically localized on smooth muscle cells of mammary ducts cannot be stated with absolute certainty. If we assume their presence, several in vivo studies on inhibition of milk removal after $\alpha-\mathrm{Ag}$ administration and in stress situations may be explained. The connection between mammary parenchyma and gland cistern may be interrupted completely or in part by $\alpha$-adrenergic receptor-stimulated smooth muscle contractions of the mammary ducts. Although oxytocin is released (Blum et al. 1989) and may cause myoepithelial contraction, no milk or only small amounts are transported to the gland cistern and only milk already available in the teat and gland cistern can be removed during milking, a view supported by studies on effects of the $\alpha$-Ag phenylephrine on milk removal and intramammary pressure before and after teat stimulation (Bruckmaier el al. 1991). Because the number of $\alpha$-adrenergic receptors in particular was very low in mammary parenchyma, the influence of the adrenergic system on this region of the mammary gland is probably relatively small.

It has been proposed that under stress conditions or after $\alpha$ - $\mathrm{Ag}$ administration oxytocin may not reach the receptors of myoepithelial cells because of decreasing blood flow to the udder due to vascular contraction after catecholamine administration through interaction with $\alpha$-adrenergic receptors in the vascular bed (Dhondt et al. 1976; Lefcourt \& Akers, 1984 ; Gorewit \& Aromando, 1985). However, only a very small increase of oxytocin concentration in blood is necessary to elicit milk ejection (Schams et al. 1984). Furthermore, vasoconstriction under stress conditions is hardly the main reason for peripheral inhibition of milk removal, because our study demonstrated only small numbers of $\alpha$-and $\beta$-adrenergic receptors in the mammary parenchyma. From in vivo studies (Bruckmaier et al. 1991), it also 
appears unlikely that $\alpha$-Ag have an effect on the responsiveness of myoepithelial cells to oxytocin. Because of the significantly higher density of $\alpha$-adrenergic receptors in teat tissue and the region of the large mammary ducts, peripheral disturbed milk removal by $\alpha-\mathrm{Ag}$ is primarily caused by constriction of the milk purging system of the udder.

It has been shown that administration of $\beta$ - Ag has a favourable effect on milk flow as a consequence of teat muscle relaxation (Bernabé \& Peeters, 1980; Hamann, 1981 ; Vandeputte-Van Messom et al. 1986). Through interaction with the numerous $\beta$-adrenergic receptors in the large mammary ducts, probably localized on smooth muscles, relaxation of the large mammary ducts is likely. Thus, after $\beta$-Ag administration, transport of milk from parenchyma tissue to the cistern is facilitated by enlarged mammary ducts and milk withdrawal accelerated after milk ejection (Blum et al. 1989; Bruckmaier et al. 1991). Mielke et al. (1991) have suggested the possibility of milk ejection after administration of $\beta$-Ag. However, lack of increased intramammary pressure by the administration of a $\beta$-Ag contradicts these findings (Bruckmaier et al. 1991).

We conclude that $\alpha$-and $\beta$-adrenergic receptors are present not only in teat walls, but also around the gland cistern and large milk ducts. Thus, the modulation of milk ejection and milk removal by the adrenergic system occurs not only during the milk's passage through the teat cavity, but also very probably during its passage from gland parenchyma to the gland cistern.

These studies have been supported by the Swiss National Science Foundation (Grant no. 32-28781.90).

\section{REFERENCES}

Bernabé, J. \& Peeters, G. 1980 Studies on the motility of smooth muscles of the teats in lactating cows. Journal of Dairy Research 47 259-275

Blum, J. W., Schams, D. \& Bruckmaier, R. 1989 Catecholamines, oxytocin and milk removal in dairy cows. Journal of Dairy Research 56 167-177

BruCkmater, R. M. \& BLUM, J. W. 1992 B-mode ultrasonography of mammary glands of cows, goats and sheep during $\alpha$ - and $\beta$-adrenergic agonist and oxytocin administration. Journal of Dairy Research 59 151-159

Bruckmaier, R., MaYer, H. \& Schais, D. 1991 Effects of $\alpha$-and $\beta$-adrenergic agonists on intramammary pressure and milk flow in dairy cows. Journal of Dairy Research $58+11-419$

Dhondt, G., Houvenaghel, A., Feys-Van De Broeck, L. \& Peeters, G. 1976 [Adrenergic receptors in blood vessels in the udder of lactating cows.] Zentralblatt für Veterinärmedizin A 23 331-337

Gorewit, R. C. \& Aromando, M. C. 1985 Mechanisms involved in the adrenalin-induced blockade of milk ejection in dairy cattle. Proceedings of the Society for Experimental Biology and Medicine $180340-347$

Hamans, J. 1981 [The influence of a $\beta_{2}$-mimetic substance (Planipart) on the milking behaviour of cows.] Tierärztliche Umschau 36 287-290

Hancock, A. A., Delean, A. L. \& Lefrowitz, R. J. 1979 Quantitative resolution of beta-adrenergic receptor subtypes by selective ligand binding: application of a computerized model fitting technique. Molecular Pharmacology 16 1-9

LefCoURT, A. M. \& AKERs, R. M. 1982 Endocrine responses of cows subjected to controlled voltages during milking. Journal of Dairy Science 65 2125-2130

Lefcovrt, A. M. \& Akers, R. M. 1984 Small increases in peripheral noradrenaline inhibit the milk-ejection response by means of a peripheral mechanism. Journal of Endocrinology $100337-344$

Mielke, H., Markov, A., Fürll, B., Kaskous, S. \& Ponce, P. 1991 [Studies on the action of the $\beta$-receptor agonist isoprenaline on mammary gland alveoli in lactating cows with particular reference to its effect on the secretory function of epithelial cells.] Monatshefte für Veterinärmedizin $46427-430$

Moor, M., Hon egger, U. E. \& Wiasmans, U. N. 1988 Organospecifie, qualitative changes in the phospholipid composition of rats after chronic administration of the antidepressant drug desipramine. Biochemical Pharniacology 37 2035-2039

Motulsky, H.J. 1987 GraphPAD (version 2.0). Philadelphia, PA: Institute of Scientific Information

Parini, A., Homcy, C.J. \& GrahaM, R. M. 1987 Structural properties of the $\alpha_{1}$-adrenergic receptor: studies with membrane and purified receptor preparations. Circulation Research 61 (Suppl.) I-100-I-104.

Roets, E. \& Peeters, G. 1985 Identification and characterization of ${ }^{3} \mathrm{H}$-Prazosin binding to $\alpha_{1}$-adrenoceptors in bovine teat muscles. Archives Internationales de Pharmacodynamie et de Thérapie $275189-198$ 
Roets, E. \& PEeters, G. 1986 A comparison of the binding characteristics of the $\alpha_{2}$-adrenoceptor antagonists ${ }^{3} \mathrm{H}$-yohimbine and ${ }^{3} \mathrm{H}$-rauwolscine in bovine teat muscles. Archives Internationales de Pharmacodynamie et de Thérapie 279 212-222

Roets, E., Peeters, G. \& Leysen, J. E. 1984 Identification of $\beta$-adrenoceptors in bovine teat muscles by ${ }^{3} \mathrm{H}$ dihydroalprenolol binding. Archives Internationales de Pharmacodynamie et de Thérapie 270 203-214

Roets, E., Vandeputte-Van Messom, G., Burvenich, C. \& Peeters, G. 1989 Relationship between numbers of $\alpha_{2}$ - and $\beta_{2}$-adrenoceptors in teat tissue and blood cells and milkability of primiparous cows. Journal of Dairy Science 72 3304-3313

SAS 1990 SAS User's Guide: Statistics. Cary, NC: SAS Institute Inc.

Schams, D., Mayer, H., Prokopp, A. \& Worstorff, H. 1984 Oxytocin secretion during milking in dairy cows with regard to the variation and importance of a threshold level for milk removal. Journal of Endocrinology 102 337-343

Shi, A. G., Aнмad, S., Kwan, C. Y. \& Daniel, E. E. 1989 Characterization of $\alpha$-adrenoceptor subtypes by $\left[{ }^{3} \mathrm{H}\right]$ prazosin and $\left[{ }^{3} \mathrm{H}\right]$ rauwolscine binding to canine venous smooth muscle membranes. Canadian Journal of Physiology and Pharmacology 67 1067-1073

Vandeputte-Van Messom, G., Burvenich, C. \& Peeters, G. 1986 Involvement of $\beta_{2}$-adrenoceptors in teat sphincter function in the lactating cow. Archives Internationales de Physiologie et de Biochimie 94 p. 34

Ziegler, H. \& Mosimann, W. 1960 Anatomie und Physiologie der Rindermilchdrüse. Berlin: Paul Parey 